\title{
The Impact of the Audit Committees' Properties on the Quality of the Information in the Banking Financial Reports: A Survey on Saudi Commercial Banks
}

\author{
Mwafag Rabab'ah ${ }^{1}$, Omar Al-Sir ${ }^{2}$, Ali A. Alzoubi ${ }^{3}$ \\ ${ }^{1}$ Assistant Professor in Finance, Institute of Public Administration, Saudi Arabia \\ ${ }^{2}$ Assistant Professor in Accounting, Institute of Public Administration, Saudi Arabia \\ ${ }^{3}$ Associate Professor in Accounting, Ajloun National University, Jordan \\ Correspondence: Mwafag Rabab'ah, Assistant Professor in Finance, Institute of Public Administration, Saudi \\ Arabia.
}

Received: June 5, 2017

doi:10.5539/ibr.v10n11p175
Accepted: August 21,2017

Online Published: October 18, 2017

URL: https://doi.org/10.5539/ibr.v10n11p175

\begin{abstract}
This study aims to identify the impact of the audit committees' properties on the quality of the information of the banking financial reports in the Saudi commercial banks by identifying the effect of identifying tasks and duties, independence, accounting and banking experience and efficiency of the audit committee on achieving the quality of the Saudi banking and financial reports. 110 questionnaires were distributed on the research sample and 105 questionnaires were received and analyzed through ANOVA. Results indicate that the availability of the audit committees' properties affect increasing the quality of the financial reports in the Saudi banking at the level of properties as a whole where the $(\mathrm{P})$ probable value was $(0.000)$, which is less than 0.05 . It represents the functions and duties of the audit committee, the committee's independence in banks, the availability of the accounting and banking experience for the members of the audit committee and the efficiency of the audit committees at banks. The study recommends more emphasis on the diversity of the experiences of the members of the audit team and thus; the committee can performs its functions in a more efficient and effective way.
\end{abstract}

Keywords: commercial banks, audit committee, the quality of financial reports, banking accounting experience

\section{Introduction}

Attention has been increased with the presence of the audit committees in the companies in recent times after many cases of financial collapse and corruption in a large number of companies in many countries. Additionally, the main functions of the audit committees turned to examine the financial reports, whether periodic or annual, and describe them before submitting them to the board of directors. The reason is that the foundation of forming the audit committees in companies is to ensure the quality of the financial reports, the availability of quality in information and to expand the benefits of such information.

Currently, the audit committees have received an increasing attention from the public shareholding companies because they are considered a fundamental pillar of the quality of the financial reports information. Accordingly, there must be certain properties in the committee enabling it to perform its duties properly. Therefore, this study is to highlight the impact of the audit committees' properties on achieving the quality of the financial reports of the Saudi commercial banks through the comprehensiveness of the accounting disclosure of information needed by the users of accounting information in the Kingdom of Saudi Arabia.

Research Problem: The research problem is that the audit committees of banks should be characterized by certain characteristics enabling them to perform their supervisory and control role on the financial performance of banks in selecting and isolating the financial references and reports which can affect the quality of the published financial reports of these banks. Subsequently, the problem can be addressed in the following questions:

The Main Question: Does the availability of the qualitative characteristics of the audit committee affect the achievement of the quality of the information of the banking financial reports? The following questions are stemmed from it: 
1. What is the impact of the predetermination of the functions and duties of the audit committee on the quality of the information of the banking financial reports?

2. Does the independence of the members of the audit committee affect the quality of the information of the banking financial reports?

3. Does the availability of the accounting and banking experience of the members of the audit committee affect the quality of the financial banking reports?

4. What is the impact of the efficiency of the audit committees in banks on the quality of the information of the banking financial reports?

Research Importance: the importance of the study can be addressed through the following:

1. Scientific (theoretical) importance: Bridging the gap in the published studies on the impact of the audit committees by focusing on the properties of the audit committees and linking them with the quality of the information of the banking financial reports, and alerting researchers and those interested in the subject for conducting more research on the subject of audit committees.

2. practical (applied) importance: the research contributes in clarifying the importance of having certain characteristics in the audit committees in the Saudi commercial banks to achieve the quality of financial reports. It is expected that this study contributes to the statement of the audit committe es' practices in the Saudi commercial banks and their ability to achieve the quality of the information of the banking financial reports and achieve the efficiency and effectiveness of their internal controls.

Therefore, the study mainly aims to investigate the impact of the audit committee's properties on the quality of the published information of the banking financial reports for the Saudi commercial banks by identifying the impact of the audit committees' properties (determining tasks and duties, independence, accounting and banking experience and efficiency of the audit committee) on achieving the quality of the information of the Saudi banking financial reports.

Methodology: The descriptive, analytical approach is used to describe the phenomenon and analyze the data through the distribution of the questionnaire form to a sample of Saudi commercial banks and analyzing it by the statistical methods using the SPSS.

Research Hypotheses: The research examines the following hypotheses:

Main Hypothesis: there is a statistically significant effect for the identification of the characteristics of the audit committee in the quality of the information of the banking financial reports. The following assumptions are stemmed from it:

1. There is a statistically significant impact to determine the functions and duties of the audit committee on the quality of the information of the banking financial reports.

2. There is a statistically significant effect of the independence of the audit committee on the quality of the information of the banking financial reports.

3. There is a statistically significant impact for the availability of the banking accounting experience for the members of the audit committee on the quality of the information of the banking financial reports.

4. There is a statistically significant effect of the efficiency of audit committees in banks on the quality of the information of the banking financial reports.

\section{Procedural Definitions of the Study Variables:}

1. The independence of the audit committee: a sub-committee composing of a number of the board members whose members are independent (non-executive); it acts as a liaison to coordinate the work of the external auditor and management leading to support the auditor's independence, which is addressed through:

a. Determining the functions and duties of the audit committee: it is represented in reviewing the financial statements, appointing the external auditor, audit plan and results, internal control system and ensuring the quality of the accounting information

b. The independence of the audit committee: it means that the members of the audit committee are enjoyed with full independence from the executive management and that they are free to express their opinion in the performance entirely.

c. Banking and financial experience: the members of the audit committee should be fully aware of the accounting principles and basics as well as the banking risks. 
d. The efficiency of the members of the audit committees: it is concerned with the efficiency in the performance of the job and the tasks properly and this is achieved by planning, organization and supervision.

2. The dependent variable: the quality of the information of the banking financial reports: the information is described as good if it is characterized by specific qualities that meet the needs of their users.

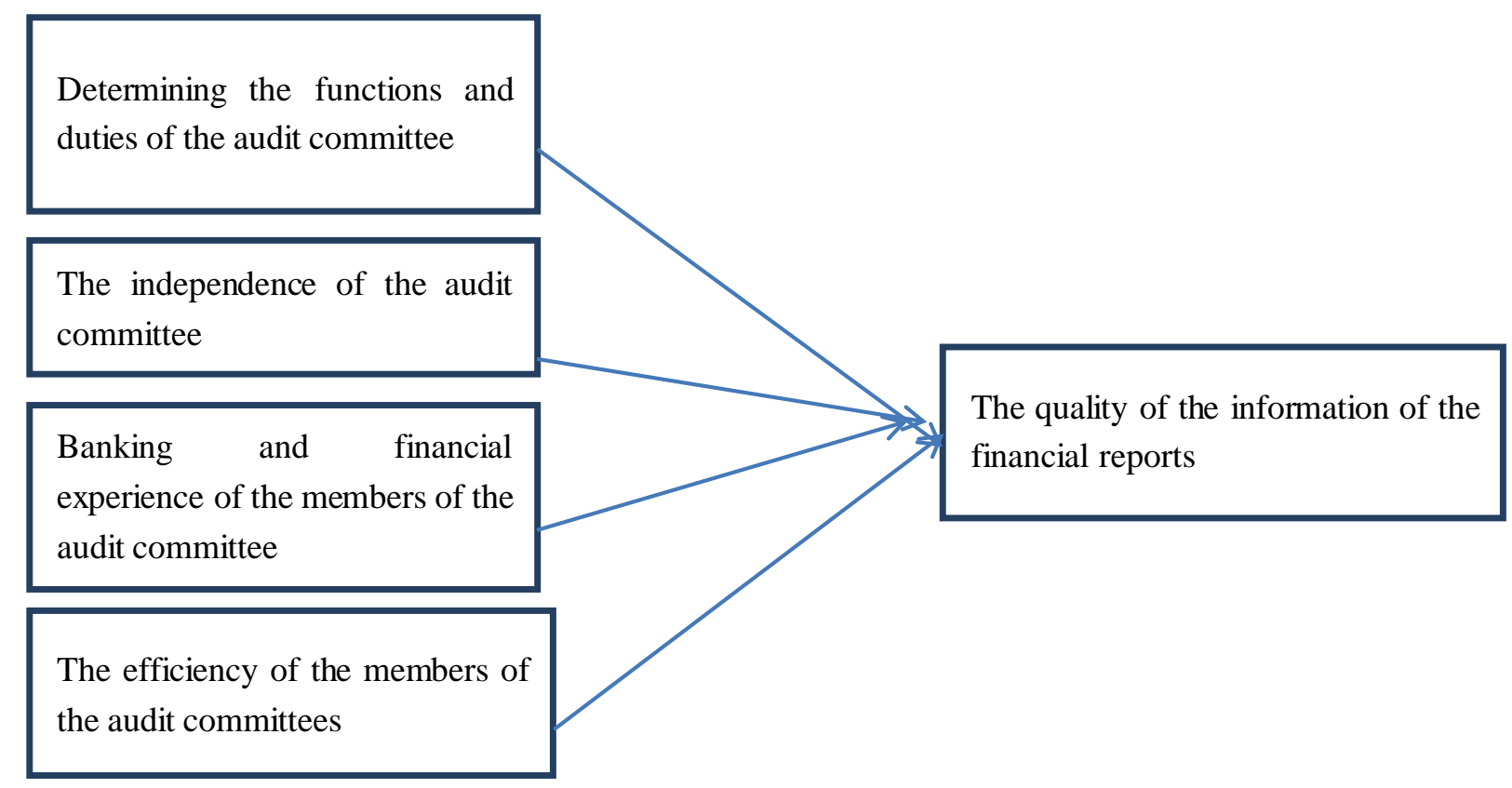

Figure 1. variables of the research model

\section{Research Organization:}

The research was divided into four areas: the general framework of the research, the theoretical framework and previous studies, the field study and the findings and recommendations.

\section{Literature Review}

The concept of audit committees: it is a committee consisting of the members of part-time members of the Board of Directors to supervise the function of the internal audit which increases the independence of the internal audit department; the greater the relationship between the audit committee and the management of the internal audit, the more the availability of independence and objectivity in examination and report (Abu Saud, 2005: p. 334). It is also known as "a committee that is represented in the number of the members of the board of Directors who hold the responsibility of helping reviewers (among other responsibilities) so as to maintain the neutrality of the administration" (Odeniz and Bock, 2005: p. 123).

Importance of Audit Committees: The importance of audit committees is represented in the following: (Radhi 2010: p. 481):

1. Maintaining the auditor's independence (indoor, outdoor) since the audit committee represents the link between the auditor and the company's management; however, there are many factors, whether economic or accounting leading to increasing importance of audit committees, which are:

A-great development and expansion in the economic activities and the growing importance of public shareholding companies.

B- Weakness of the regulatory system in the joint-stock companies, and the administration's pressure on the external auditor on some issues.

C-proliferation of lawsuits against private auditors especially in the USA.

D-the role of the audit committee in reducing the incidence of fraud, manipulation, the increase of the effectiveness of the internal control environment and strengthening the auditor's independence.

2. Asking for money markets from all the listed companies in the financial market companies to have audit committees; most recommendations called for audit committees and that their members should be non-executive 
members of the board of directors and at least, they should not be employees of the company (Al-Ashmawi, 2006).

Audit Committees characteristics: The basic characteristics of audit committees are as follows:

1. The clarity of the functions and duties of the audit committee of the bank: some believe that there must be a set of controls so that the committee can claim its functions efficiently and effectively (Nasr and Shehata, 2006: p. 304):

(A) A clear identification of powers and responsibilities of the committee that the powers and responsibilities of the audit committee should be determined in a detailed and clear way.

(B) The need of the availability of experience and training among the members of the audit committee; it is also agreed that the members of the audit committee must be non-executives and be characterized with ability, experience and skill in following up and assessing the internal control systems.

(C) The need of determining the appropriate number of the members of the audit committee: it is necessary to determine the number of the members of the audit committee to ensure it is enough to bring more expertise and capacities that will enable the committee to achieve its goal.

2. Committee's independence at banks: it is one of the most important characteristics that must be available among the members of the audit committee where the independence allows the audit committee to carry out its duties and responsibilities and help it make decisions without bias; the audit committee must be composed of consultants that serve as an advisory body for the auditors' work and it must be independent from the management; this was confirmed by Tredaoa Committee Report in 1987, which presented many recommendations to curb fraud in the financial statements and improve the regulatory performance in the facilities and present independent audit committees that supervise the independence of the external and the internal auditors (Al-Saka, 1995: p. 30).

3. The availability of the banking and accounting experience among the members of the Audit Committee:

Through the confirmation of the independence element and activities, the audit committees are linked with selecting individuals with experience in this field and determining and defining their experience and characteristics as well as the importance of defining independence; the most important recommendations of BRC Committee were supporting the role of audit committees since the first recommendation is related to defining the independence of audit committees and their period and the second recommendation is related to the experience and training of the members of the audit committee and the qualifications of its members in terms of the banking and financial aspects (Al-Wabil, 1996 : p. 30).

4. Efficiency of audit committees in banks:

In order that the audit committee carry out its functions efficiently, it must have the ability to get the proper information at the right time; there are some characteristics making the audit committees do their job efficiently and effectively, such as (Radi, 2010: 451):

1. The formation of the audit committee of a number of non-executive members of the board of directors who must not be less than three; the members must have one expert in the financial and accounting affairs; one member or more should be appointed from outside the non-executive members of the board of directors.

2. The Committee should meet regularly with a specific program not less than once in three months.

3. The company must de velop sufficient capabilities at the disposal of the committee and it must help it perform its job including the help of experts.

From the above, we conclude that there must be some basic characteristics enabling the audit committees to perform their various tasks.

The concept of financial reports: Financial reports are the product of the accounting system. They must contain true, accurate and appropriate information for the purpose intended for in the right time (Jarbou, 2001: p. 164) and it is defined by (AL-fadag, 2002: p. 23) as "means to deliver information related to accounting which are not limited to the financial statements". (Radi, b, 2004: 7) defined it as "the main means used to connect the financial information to the external parties and it includes the balance sheet, income statement, cash flow statement, and changes in equity statement; the financial reports do not include the financial statements only but they extend to include other means to connect related or unrelated information that is extracted from the accounting system" (Hammad, 2005: p. 35).

\section{Characteristics of the information provided in the financial reports:}

The characteristics of the information provided in the financial reports are as follows: 
1. Relevance, information is relevant when it affects the economic decisions of users by helping them correct the past and current events in the estimation of the net cash flows or confirming or correcting the previous estimates (FASB, 2006); its main goal is choosing the methods of measurement and disclosure that help people who rely on the financial statements to make decisions.

2. The relative (physical) importance, the degree of the information's impact on decision makers; it is linked to a range of considerations, including the type of information, whether regular or irregular and the extent of their relationship with certain decisions at the enterprise level, or the level of its users (Atiya, 1999: p. 46 ); the relative importance depends on the estimated size of the error in the light of the special circumstances of deletion or distortion (Hammad, b, 2006: 93).

3. Reliability, information has reliability if it is free of errors and far from bias; users can rely on it as information accurately reflecting what is intended to express or what is expected to express (Aldahrawi, 2004: p. 38).

4. Neutrality, it means impartiality; this element interferes clearly with the reliability of the information because the biased information by its nature cannot be relied on (financial accounting commission for banks and financial and Islamic institutions, 1994: p. 36)

5. Comparability, it means the characteristics that make the comparison possible in order to facilitate analysis, forecasting and decision-making by creditors, investors and others (Hanan, 2003: p. 207); the information that is measured and presented in the same way are considered comparable; it also enables users to verify the similarities and differences in the economic phenomena.

6. Consistency, it means the need to apply the accounting methods and policies from one period to another unless there were significant changes calling for a change in these policies; this property is linked to the viability of comparable information and it is considered a property overlapping between convenience and reliability in a manner that achieves the usefulness of the information.

You can say that the basic characteristics of the audit committees help them do their main job and help maintain the quality of the financial reports information.

\section{Previous Studies}

The previous studies related to the variables of the study are presented as follows:

1. (Memullen D, 1996): The problem of the study is represented in the role of the audit committees in increasing the accuracy of the information published in the financial statements. It aimed to identify the role of the audit committees in increasing the accuracy of the information published in the financial statements for two groups of US companies. It resulted that the companies have audit committees if the external auditor is not changed or isolated when there is a professional disagreement, if there is a relative decrease in the incidence of illegal financial actions and if the degree of confidence in the financial statements information increases especially for the businesses with their listed shares in the stock exchange.

2. (Noland et.al, 2004): the study problem is identifying the added value of the commercial banks having audit committees and the quality of the audit committees that benefit the commercial banks. The study aimed to analyze the added value added by the presence of audit committees in the small commercial banks. The study found that the presence of audit committees in banks is insufficient because of the sensitive nature of the banking business; therefore, the audit committees must at least have a member with banking and financial experience, which helps reduce irregularities in legislations for the organization, cases of embezzlement and theft by the employees as well as irregularities and technical mistakes in the job. Accordingly, the results of this study confirm the importance of the presence of members experienced in the field of work practiced by the foundation within the audit committees of this institution.

3. (Shami, 2006): The study problem is represented in answering the question of what is the impact of audit committees on the quality of the financial reports information? This study showed the importance of composing audit committees since they support the objectivity and credibility of raising the quality level, support confidence in the quality of the financial reports, reduce manipulation by the management, improve the quality of the internal audit level, provide protection for users of financial reports, strengthen the independence of the external auditor, and reduce shortcomings in controlling the financial report.

4. (Schadéwitz \& Turley 2008): the study problem lies in the analysis of the characteristics of the audit committee with the quality of the financial reports and the study concluded that if the financial size and expertise did not affect the audit committee, the committee should audit the estimated profits; the most active audit 
committees are better able to determine the earnings management and then contribute to the quality of the financial reports since the active audit committee is well-informed on the state of the company or it is equipped with members who devoted their time and effort to work in the committee which leads to better control.

5. (Sori, et. Al, 2009) The study conducted. sought to know the role of audit committees in supporting the independence of the external auditor. The study was conducted on the financial companies listed in the Malaysian financial market in an attempt to improve the control procedures that support the corporate governance. Questionnaires were distributed on 87 bank agents in addition to interviews conducted with bank employees. Results showed that the majority of respondents confirmed that the independence of the external auditors was supported through the audit committees.

6. (Qutaishat, 2010): the study problem lies in the availability of characteristics needed to improve efficiency within the audit committees formed in the Jordanian public shareholding companies. Do the audit committees perform the necessary tasks to achieve efficiency? the study also showed that the majority of the audit committees of the companies do their tasks entrusted to them by the external auditor, internal audit and the board of directors; the preference was for the financial sector followed by the service sector in practicing the tasks of the committee; as for the industrial sector, the study showed that there was a negligence in committee's practice of those tasks.

7. (Labib, 2011): The problem of the study is represented in the presence of deficiencies in the role of audit committees in restricting and reducing profits by the financial reports through answering the following main question: does setting a proposed framework for improving the effectiveness of the audit committees reduce profits through the financial reports; the study reached to several conclusions, including, the presence of a positive effect for the presence of the audit committee in reducing the profits management operations by the management leading to improving the quality of profits, developing and activating the properties and activities of the audit committee in the companies in Egypt which leads to improving the quality and credibility of the financial statements.

8. (Hamdan et al., 2012): The study problem is stated through the following questions: are the Jordanian public shareholding companies committed to the characteristics of the audit committees contained in the laws and regulations of Jordan. Do the profits announced by the Jordanian public shareholding companies characterized by quality? Is there an effect for the characteristics of the audit committee on improving the quality of the undisclosed profits? The study found a positive effect for the number of meetings of the audit committee in improving the quality of profits, a negative effect for the ownership of the company's shares by the members of the audit committee on the quality of profits and the lack of effect of the audit committees' characteristics such as the size of the audit committee, members' independence and experience on improving the financial quality of profits.

9. (Carcinoid, 2013): The study problem is represented in the extent of the adoption of the characteristics of the effectiveness of audit committees by the Jordanian laws and regulations, the commitment of the Jordanian public shareholding companies to apply the characteristics of effectiveness, and whether those characteristics impact in the reduction of earnings management. This study concluded that the Jordanian public Shareholding companies are committed to the application of the regulations of the private corporate governance by the characteristics of the audit committees as mentioned in the Jordanian legislations and that the characteristics of the audit committees represented in the size of the audit committees, the financial expertise of their members and the number of their meeting do not affect the reduction of earnings management; howe ver, the independence of the members of the audit committees affect reducing the profits' management.

10. (Ali, 2013): The study problem is represented in studying the relationship between the audit committee and the effectiveness of the internal control in the Sudanese banks; the study aimed to evaluate the role of the audit committees in increasing the confidence level in the performance of the internal control in the Sudanese banks, determining the extent of the impact and implications of each factor of independence, experience, size and tasks in supporting the quality of the performance of audit committees for the purposes of achieving efficiency and effectiveness of the internal control in the Sudanese banks, and shedding light on the effectiveness of the performance of audit committees on achieving the internal control targets in the Sudanese banks. The study found a positive relationship between the independence, experience, size and functions of the audit committee and the effectiveness of the quality of the internal control in the Sudanese banks.

11. (Khallat \& Masli, 2014): The study problem is focused on the question: What is the extent of the need for forming audit committees to support the efficiency and effectiveness of the internal audit in the Libyan industrial companies? The study concluded that there is an agreement among the participants in the study that the 
formation of audit committees in the Libyan industrial companies contribute to the support and efficiency of the internal audit functions and the need for a set of considerations that enable the audit committee to support the efficiency and effectiveness of the internal audit function.

12. (Rachman \& Gunawan, 2014) The study conducted by aimed to examine the effect of internal auditors, audit committees and board of commissioners on the quality of financial reports. The empirical study examined 22 banks listed in the Indonesian financial market in 2012. The study demonstrated a positive effect of the board commissioners with a percentage of $(25.37 \%)$, a positive effect of the audit committees with a percentage of $(19.35 \%)$, and a positive effect of internal auditors with a percentage of (30.41). However, the positive effect of other factors was not examined in this study.

13. (Kabbjee, 2015) the study's problem is represented in the role played by the audit committees in the study and evaluation of the internal control systems and their role in supporting the function of the internal auditor to carry out the tasks related to the assessment of the bank's policies related to money laundering; the study has come out with several conclusions, including that the audit committees should be committed to applying the tasks and responsibilities assigned to them, should enjoy necessary practices to do their tasks effectively in fighting the money laundering powers, and that they should contribute to the evaluation of the internal control system, support the function of the internal audit and support the external audit in fighting the money laundering operations.

14. (Al-Hassan, \& Shabu, 2015) the study problem consisted of the fact that the composition of audit committees in the commercial banks do not take into account the efficiency and the financial and accounting expertise of the members of the audit committee, which showed a gap between the performance of the audit committee and the confidence of the financial reports in such banks; the study found that audit committee's lack of familiarity with the accounting principles reduced the efficiency of the performance of the external auditor, which lays doubts on the credibility of the financial statements, the lack of independence of audit committees in the banks from the executive management has weakened the control role of the committee and helped reducing the quality level of the professional performance of the external auditor and finally the lack of the clarity of the legal responsibility associated with the report of the audit committee that reduced the level of transparency in the financial reports of the bank.

15. (Mal et al. 2015) The study aimed to know the effect of the audit committees on the quality of the Nigerian financial reports through its characteristics, independence, and the held meetings. The study examined the financial reports of a sample involved the Nigerian banks in the period from 2003 to 2012. Pearson factor along with linearity were used. Results reached that the independence of the audit committees has a negative effect on the financial reports. Further, the held meetings conducted by the audit committees have a positive effect on the quality of the financial reports.

16. (Al-Matari et al. 2016) studied the effect of the characteristics of the Audit committees on the performance of the Yemeni banks by focusing on the meetings conducted between audit committees and internal auditors. The focus was placed on the suggestions and results of internal auditors work. The empirical study included a sample of 20 Yemeni banks through distributing 112 questionnaires. Results showed the importance of audit committees' role and the existence of a significant relationship between the audit committees and the banks performance.

17. (Kusnadi et al. 2016) conducted a study to examine the role of the audit committees through elements of independence, experience and the overlapped membership and their role in financial quality reports in the listed companies in Singapore. Results showed that the quality of the financial reports is much better of the various elements audit committees. Additionally, the independence of audit committees supports the quality financial reports and verify that there is no effect for overlapped membership on the quality reports.

\section{Methods}

The Study Sample and Population: the original study community consisted of a part of the Saudi commercial banks amounting to (11). The study sample consisted of four banks (36\%) of the study population and it was selected randomly as the researchers distributed (110) questionnaires to the respondents out of whom 105 (95.5\%) answered and returned the questionnaires after filling them with the required information in 2016.

Study Tool Description: the research tool is the means used in the initial collection of data on the phenomenon in question and the researchers have relied on the questionnaire as a tool to collect data of the study; the questionnaire was divided into two parts as follows:

The first section includes the personal information which includes five points:

1. Age: 
Table 1. Frequency distribution of the members of the study sample according to the variable of age

\begin{tabular}{lll}
\hline Age group & Frequency & Percentage \% \\
\hline Less than 25 years old & 15 & 14.3 \\
$25-35$ & 51 & 48.6 \\
$35-45$ & 28 & 26.7 \\
$45-55$ & 11 & 10.5 \\
55 and above & 0 & 0 \\
Total & 105 & 100.0 \\
\hline
\end{tabular}

The figure below shows the graph of the age groups

Table 1 shows that $14.3 \%$ of the members of the study sample are under 25 years, $48.6 \%$ are (25-35), $26.7 \%$ are (35-45) and $10.5 \%$ are ( 45-55).

\section{Scientific Specialization:}

Table 2. Frequency distribution of the members of the study sample according to the variable of scientific specialization

\begin{tabular}{lll}
\hline Specialization & Frequency & Ratio $\%$ \\
\hline Accounting & 29 & 27.6 \\
Financial management & 13 & 12.4 \\
Business Administration & 35 & 33.3 \\
HR management & 7 & 6.7 \\
Other & 21 & 20.0 \\
Group & 105 & 100.0 \\
\hline
\end{tabular}

Table 2 shows that $27.6 \%$ of the respondents are specialized in accounting, $12.4 \%$ in financial management, $33.3 \%$ in Business Administration, $6.7 \%$ in human resources management and finally $20 \%$ in different specialties.

\section{Scientific Qualification:}

Table 3: Frequency distribution of the members of the study sample according to the scientific qualification

\begin{tabular}{lll}
\hline Qualification & Frequency & Percentage $\%$ \\
\hline High School & 5 & 4.8 \\
Diploma & 26 & 24.8 \\
BA & 74 & 70.5 \\
M.A. & 0 & 0 \\
Other & 0 & 0 \\
Total & 105 & 100.0 \\
\hline
\end{tabular}

Table No. 3 shows that $70.5 \%$ of the members of the study sample hold the BA, $24.8 \%$ the Diploma, and $4.8 \%$ the secondary qualification.

\section{Career position:}

Table 4. Frequency distribution of the members of the study sample according to career position

\begin{tabular}{lll}
\hline Position & Frequency & Ratio \% \\
\hline administrator / Director & 31 & 29.5 \\
Member of the Audit Committee & 5 & 4.8 \\
Member of the audit team & 5 & 4.8 \\
Employee & 63 & 60.0 \\
Other & 1 & 1.0 \\
Total & 105 & 100.0 \\
\hline
\end{tabular}

Table 4 shows that $29.5 \%$ of the members of the study hold an administrative position, $4.8 \%$ of the respondents are among the members of the Audit Committee, $4.8 \%$ of the respondents are among the members of the audit team, $60 \%$ of the respondents are employees and finally $1 \%$ of the respondents occupy other positions. 


\section{Years of Experience:}

Table 5. Frequency distribution of the members of the study sample according to years of experience

\begin{tabular}{lll}
\hline Years of Experience & Frequency & Percentage $\%$ \\
\hline Less than 5 & 30 & 28.6 \\
$5-10$ & 43 & 41.0 \\
$10-15$ & 18 & 17.1 \\
$15-20$ & 11 & 10.5 \\
More than 20 & 3 & 2.9 \\
Total & 105 & 100.0 \\
\hline
\end{tabular}

Table No. (5) shows that $28.6 \%$ of the members of the study sample have less than 5 years of experience, $41 \%$ of them had (5-10 years) of experience, $17.1 \%$ of them had (10 -15) years of experience, $10.5 \%$ had (15-20) years and finally $2.9 \%$ had more than twenty years of experience.

\section{Validity and reliability of the study tool:}

1. Arbitrators' validity: the researchers presented the questionnaire to a group of arbitrators composed of six specialists in the field of accounting and the researchers responded to the viewpoints of the arbitrators and conducted deletions and modifications in light of the submitted suggestions.

2. Scale's Validity through:

a. Cronbach's alpha coefficient: the researchers used Cronbach's alpha to measure the reliability of the questionnaire, and the results were as follows:

Table 6. Cronbach's alpha coefficient

\begin{tabular}{ll}
\hline Cronbach's alpha coefficient Value & number of items \\
\hline 885 & 24 \\
\hline
\end{tabular}

Table 6 shows that the high value of Cronbach alpha coefficient was (0.885) which indicates the reliability of the questionnaire.

Measuring the degree of reliability and validity of each axis of the questionnai re:

Table 7. Reliability and validity of each axis of the questionnaire

\begin{tabular}{lll}
\hline Axis & $\begin{array}{l}\text { Reliability } \\
\text { coefficient }\end{array}$ & Validity \\
\hline Tasks and duties of the audit committee of the bank & .0 .768 & .876 \\
committee independence at banks & .847 & 0.920 \\
The availability of the accounting and banking experience for the members of the & .777 & .881 \\
Audit Committee & .793 & 0.891 \\
efficiency of audit committees at banks
\end{tabular}

Table 7 Shows that the validity of the axes of the study was: $(0.876,0.920,0.881,0.891)$, respectively; such results are an indication that the results of the study can be circulated to the society from which the sample was taken. The reliability values of the study axes were $(0.768,0.847,0.777$, and 0.793$)$, respectively; furthermore, the total reliability of the study, which is an indication of the validity of the study tool (questionnaire) was used for the purpose of achieving the objectives of the study by ans wering its questions that it was (0.885); the value of the high reliability of the study tool on the possibility of the prediction of the results' reliability which can be resulted when application. 


\section{Descriptive statistics of the study data:}

The first axis: functions and duties of the audit committees of banks

Table 8. Frequency distribution, arithmetic mean and standard deviation of the first axis

\begin{tabular}{|c|c|c|c|c|c|c|c|c|c|c|c|c|c|c|}
\hline \multirow[t]{2}{*}{ No. } & \multirow[t]{2}{*}{ Phrase } & \multicolumn{2}{|c|}{$\begin{array}{l}\text { Strongly } \\
\text { Disagree }\end{array}$} & \multicolumn{2}{|c|}{ disagree } & \multicolumn{2}{|c|}{ neutral } & \multicolumn{2}{|c|}{ agree } & \multicolumn{2}{|c|}{$\begin{array}{l}\text { Strongly } \\
\text { agree }\end{array}$} & \multirow{2}{*}{$\begin{array}{l}\text { Arith metic } \\
\text { mean }\end{array}$} & \multirow{2}{*}{$\begin{array}{l}\text { standard } \\
\text { deviation }\end{array}$} & \multirow[t]{2}{*}{$\begin{array}{l}\text { Sort by } \\
\text { importance }\end{array}$} \\
\hline & & $\mathrm{T}$ & $\%$ & $\mathrm{~T}$ & $\%$ & $\mathrm{~T}$ & $\%$ & $\mathrm{~T}$ & $\%$ & $\mathrm{~T}$ & $\%$ & & & \\
\hline 1 & $\begin{array}{l}\text { The issuance of the } \\
\text { audit committee } \\
\text { reports is done } \\
\text { within the annual } \\
\text { reports of the bank }\end{array}$ & 1 & 1 & 4 & 3.8 & 7 & 6.7 & 21 & 20 & 72 & 68.6 & 4.51 & .856 & 1 \\
\hline 2 & $\begin{array}{l}\text { regular meetings are } \\
\text { held for the } \\
\text { members of the } \\
\text { audit committee of } \\
\text { the Bank }\end{array}$ & 0 & 0 & 0 & 0 & 6 & 5.7 & 30 & 28.6 & 69 & 65.7 & 4.60 & .598 & 3 \\
\hline 3 & $\begin{array}{l}\text { The audit committee } \\
\text { presents the results } \\
\text { of its job to the } \\
\text { bank's board of } \\
\text { directors }\end{array}$ & 0 & 0 & 0 & 0 & 3 & 2.9 & 34 & 32.4 & 68 th & 64.8 & 4.62 & .544 & 4 \\
\hline 4 & $\begin{array}{l}\text { the performance of } \\
\text { the executive } \\
\text { management is } \\
\text { assessed and a } \\
\text { report is sent to the } \\
\text { bank's board of } \\
\text { directors }\end{array}$ & 3 & 2.99 & 2 & 1.9 & 6 & 5.7 & 34 & 32.4 & 60 & 57.1 & 4.39 & .904 & 5 \\
\hline 5 & $\begin{array}{l}\text { Concerning with the } \\
\text { regulatory } \\
\text { procedures and } \\
\text { protecting the bank } \\
\text { assets }\end{array}$ & 0 & 0 & 0 & 0 & 5 & 4.8 & 31 & 29.5 & 69 & 65.7 & 4.61 & 0.580 & 2 \\
\hline 6 & $\begin{array}{l}\text { It conducts } \\
\text { supervision } \\
\text { immediately to } \\
\text { check on } \\
\text { the performance of } \\
\text { the bank }\end{array}$ & 7 & 6.7 & 3 & 2.9 & 3 & 2.9 & 33 & 31.4 & 59 & 56.2 & 4.28 & 1.114 & 6 \\
\hline & Full axis & & & & & & & & & & & 4.13 & 0.717 & agree \\
\hline
\end{tabular}

Table 8 shows that the general trend is "agree" to all the phrases of the axis with an arithmetic mean of 4.13 and a standard deviation of 0.717 
The second axis: the independence of the audit committees in banks

Table 9. frequency distribution, arithmetic mean and standard deviation of the second axis

\begin{tabular}{|c|c|c|c|c|c|c|c|c|c|c|c|c|c|c|}
\hline \multirow[t]{2}{*}{ No. } & \multirow[t]{2}{*}{ Phrase } & \multicolumn{2}{|c|}{$\begin{array}{l}\text { Strongly } \\
\text { Disagree }\end{array}$} & \multicolumn{2}{|c|}{ disagree } & \multicolumn{2}{|c|}{ neutral } & \multicolumn{2}{|c|}{ agree } & \multicolumn{2}{|c|}{$\begin{array}{l}\text { Strongly } \\
\text { agree }\end{array}$} & \multirow{2}{*}{$\begin{array}{l}\text { Arith metic } \\
\text {-mean }\end{array}$} & \multirow{2}{*}{$\begin{array}{l}\text { standard } \\
\text { deviation }\end{array}$} & \multirow[t]{2}{*}{ Ranking } \\
\hline & & $\overline{\mathrm{T}}$ & $\%$ & $\mathrm{~T}$ & $\%$ & $\mathrm{~T}$ & $\%$ & $\mathrm{~T}$ & $\%$ & $T$ & $\%$ & & & \\
\hline 1 & $\begin{array}{l}\text { There are nonexecutive } \\
\text { members in the audit } \\
\text { committee }\end{array}$ & 3 & 2.9 & 7 & 6.7 & 20 & 19 & 35 & 33.3 & 40 & 38.1 & 3.97 & 1.051 & 4 \\
\hline 2 & $\begin{array}{l}\text { The selection and election of } \\
\text { the audit committee is done } \\
\text { by shareholders and with the } \\
\text { participation of the board of } \\
\text { directors }\end{array}$ & 7 & 6.7 & 6 & 5.7 & 22 & 21 & 39 & 37.1 & 31 & 29.5 & 4.77 & 1.137 & 5 \\
\hline 3 & $\begin{array}{l}\text { The bank's audit committee } \\
\text { participate in the bank in one } \\
\text { session }\end{array}$ & 5 & 4.8 & 8 & 7.6 & 21 & 20 & 44 & 41.9 & 27 & 25.7 & 3.76 & 1.070 & 6 \\
\hline 4 & $\begin{array}{l}\text { There are specific } \\
\text { requirements for punishing } \\
\text { the audit committee in the } \\
\text { case of its involvement in } \\
\text { corruption }\end{array}$ & 7 & 6.7 & 0 & 0 & 13 & 12.4 & 41 & 39 & 44 & 41.9 & 4.10 & 1.070 & 2 \\
\hline 5 & $\begin{array}{l}\text { The independence of the } \\
\text { audit committee is assessed } \\
\text { by other parties on a regular } \\
\text { basis }\end{array}$ & 3 & 2.9 & 1 & 1 & 14 & 13.3 & 45 & 42.9 & 42 & 40 & 4.16 & 0.900 & 3 \\
\hline 6 & $\begin{array}{l}\text { There are procedures, laws } \\
\text { and regulations that control } \\
\text { the job of the audit control }\end{array}$ & 0 & 0 & 0 & 0 & 8 & 7.6 & 35 & 33.3 & 62 & 59 & 4.51 & 0.637 & 1 \\
\hline & Full axis & & & & & & & & & & & 4.32 & .519 & $\begin{array}{l}\text { Strongly } \\
\text { Agree }\end{array}$ \\
\hline
\end{tabular}

Table 9 shows that the general trend is "strongly agree" to all the phrases of the axis by an arithmetic mean of 4.32 and a standard deviation of 0.519

The third axis the banking and accounting experience of the members of the bank's audit committee

Table 10. Frequency distribution, arithmetic mean and standard deviation for the third axis

\begin{tabular}{|c|c|c|c|c|c|c|c|c|c|c|c|c|c|c|}
\hline \multirow[t]{2}{*}{ No. } & \multirow[t]{2}{*}{ Phrase } & \multicolumn{2}{|c|}{$\begin{array}{l}\text { Strongly } \\
\text { Disagree }\end{array}$} & \multicolumn{2}{|c|}{ disagree } & \multicolumn{2}{|c|}{ neutral } & \multicolumn{2}{|c|}{ Agree } & \multicolumn{2}{|c|}{$\begin{array}{l}\text { Strongly } \\
\text { agree }\end{array}$} & \multirow[t]{2}{*}{$\begin{array}{l}\text { Arith metic } \\
\text { mean }\end{array}$} & \multirow[t]{2}{*}{$\begin{array}{l}\text { standard } \\
\text { deviation }\end{array}$} & \multirow[t]{2}{*}{ Ranking } \\
\hline & & $\mathrm{T}$ & $\%$ & $\mathrm{~T}$ & $\%$ & $\mathrm{~T}$ & $\%$ & $\mathrm{~T}$ & $\%$ & $\mathrm{~T}$ & $\%$ & & & \\
\hline 1 & $\begin{array}{l}\text { Sufficient knowledge is available to } \\
\text { the me mbers of the audit co mmittee of } \\
\text { the banking and accounting aspects }\end{array}$ & 0 & 0 & 0 & 0 & 7 & 6.7 & 40 & 58.1 & 57 & 54.3 & 4.48 & 0.623 & 2 \\
\hline 2 & $\begin{array}{l}\text { There is a sufficient familiarity of the } \\
\text { audit criteria and the professional } \\
\text { conduct standards by the members of } \\
\text { the audit committee }\end{array}$ & 0 & 0 & 2 & 1.9 & 11 & 10.5 & 42 & 40 & 50 & 47.6 & 4.33 & .742 & 6 \\
\hline 3 & $\begin{array}{l}\text { the members of the audit committee } \\
\text { can look at the management practices } \\
\text { within the Bank }\end{array}$ & 2 & 1.9 & 0 & 0 & 14 & 13.3 & 34 & 32.4 & 55 & 52.4 & 4.33 & .851 & 3 \\
\hline 4 & $\begin{array}{l}\text { Training seminars are organized for } \\
\text { the me mbers of the audit committee in } \\
\text { the accounting field }\end{array}$ & 2 & 1.9 & 2 & 1.9 & 16 & 15.2 & 31 & 29.5 & 54 & 51.4 & 4.27 & .923 & 4 \\
\hline 5 & $\begin{array}{l}\text { The members of the audit committee } \\
\text { focus on studying and understanding } \\
\text { the internal control system }\end{array}$ & 0 & 0 & 1 & 1 & 8 & 7.6 & 36 & 34.3 & 60 & 57.1 & 4.48 & .681 & 1 \\
\hline 6 & $\begin{array}{l}\text { The members of the audit committee } \\
\text { study the banking risks according to } \\
\text { Basel }\end{array}$ & 2 & 1.9 & 0 & 0 & 15 & 14.3 & 37 & 35.2 & 51 & 48.6 & 4.29 & 0.852 & 5 \\
\hline & Full axis & & & & & & & & & & & 4.25 & .519 & $\begin{array}{l}\text { Strongly } \\
\text { Agree }\end{array}$ \\
\hline
\end{tabular}

Table 10 shows that the overall trend is strongly agree to all the phrases of the axis by an arithmetic mean of 4.25 and a standard deviation of 0.519 . 


\section{Axis IV: the efficiency of the bank's audit committees}

Table 11. Frequency distribution, arithmetic mean and standard deviation of the efficiency of the bank's audit committees

\begin{tabular}{|c|c|c|c|c|c|c|c|c|c|c|c|c|c|c|}
\hline \multirow[t]{2}{*}{ No } & \multirow[t]{2}{*}{ Phrase } & \multicolumn{2}{|c|}{$\begin{array}{l}\text { Strongly } \\
\text { Disagree }\end{array}$} & \multicolumn{2}{|c|}{ disagree } & \multicolumn{2}{|c|}{ neutral } & \multicolumn{2}{|c|}{ agree } & \multicolumn{2}{|c|}{$\begin{array}{l}\text { Strongly } \\
\text { agree }\end{array}$} & \multirow{2}{*}{$\begin{array}{l}\text { Arith metic } \\
\text { mean }\end{array}$} & \multirow{2}{*}{$\begin{array}{l}\text { standard } \\
\text { deviation }\end{array}$} & \multirow[t]{2}{*}{ Ranking } \\
\hline & & $\mathrm{T}$ & $\%$ & $\mathrm{~T}$ & $\%$ & $\mathrm{~T}$ & $\%$ & $\mathrm{~T}$ & $\%$ & $\mathrm{~T}$ & $\%$ & & & \\
\hline 1 & $\begin{array}{l}\text { The bank's audit } \\
\text { committee is involved } \\
\text { in the appoint ment and } \\
\text { removal of the } \\
\text { external auditor }\end{array}$ & 6 & 5.7 & 1 & 1 & 20 & 19 & 43 & 41 & 35 & 33.3 & 3.95 & 1.042 & 6 \\
\hline 2 & $\begin{array}{l}\text { The audit committee } \\
\text { studies and assesses } \\
\text { the audit plan before } \\
\text { hiring auditors }\end{array}$ & 3 & 2.9 & 1 & 1 & 16 & 15.2 & 43 & 41 & 42 & 40 & 4.14 & 0.914 & 5 \\
\hline 3 & $\begin{array}{l}\text { The audit co mmittee is } \\
\text { interested in } \\
\text { evaluating the audit } \\
\text { risk }\end{array}$ & 0 & 0 & 0 & 0 & 17 & 16.2 & 33 & 31.4 & 55 & 52.4 & 4.36 & .748 & 2 \\
\hline 4 & $\begin{array}{l}\text { There is a } \\
\text { coordination between } \\
\text { the audit committee } \\
\text { and both the internal } \\
\text { and external auditors } \\
\text { to study the auditing } \\
\text { risks }\end{array}$ & 0 & 0 & 0 & 0 & 14 & 13.3 & 37 & 35.2 & 54 & 51.4 & 4.38 & 0.712 & 3 \\
\hline 5 & $\begin{array}{l}\text { The audit committee } \\
\text { reports are directly } \\
\text { sent to the board of } \\
\text { directors }\end{array}$ & 0 & 0 & 0 & 0 & 15 & 14.3 & 34 & 32.4 & 56 & 53.3 & 4.39 & .727 & 1 \\
\hline 6 & $\begin{array}{l}\text { The audit committee } \\
\text { reports are issued } \\
\text { within the final reports } \\
\text { of the board of } \\
\text { directors }\end{array}$ & 4 & 3.8 & 0 & 0 & 12 & 11.4 & 38 & 36.2 & 51 & 48.6 & 4.26 & .941 & 4 \\
\hline & Full axis & & & & & & & & & & & 4.30 & .552 & $\begin{array}{l}\text { Strongly } \\
\text { Agree }\end{array}$ \\
\hline
\end{tabular}


The fifth Axis: the dependent variable (the quality of the information of the financial reports):

Table 12. Frequency distribution, arithmetic mean and standard deviation of the fifth axis

\begin{tabular}{|c|c|c|c|c|c|c|c|c|c|c|c|c|c|c|}
\hline \multirow[t]{2}{*}{ no } & \multirow[t]{2}{*}{ Phrase } & \multicolumn{2}{|c|}{$\begin{array}{l}\text { Strongly } \\
\text { Disagree }\end{array}$} & \multicolumn{2}{|c|}{ disagree } & \multicolumn{2}{|c|}{ neutral } & \multicolumn{2}{|c|}{ agree } & \multicolumn{2}{|c|}{$\begin{array}{l}\text { Strongly } \\
\text { agree }\end{array}$} & \multirow{2}{*}{$\begin{array}{l}\text { Arithmetic } \\
\text { mean }\end{array}$} & \multirow{2}{*}{$\begin{array}{l}\text { standard } \\
\text { deviation }\end{array}$} & \multirow[t]{2}{*}{ Ranking } \\
\hline & & $\mathrm{T}$ & $\%$ & $\mathrm{~T}$ & $\%$ & $\mathrm{~T}$ & $\%$ & $\mathrm{~T}$ & $\%$ & $\mathrm{~T}$ & $\%$ & & & \\
\hline \multirow[t]{2}{*}{1} & The financial & & & & & & & & & & & & & 4 \\
\hline & $\begin{array}{l}\text { information is } \\
\text { published at the } \\
\text { right time. }\end{array}$ & 1 & 1 & 2 & 1.9 & 9 & 8.6 & 42 & 40 & 51 & 48.6 & 4.33 & .793 & \\
\hline \multirow[t]{2}{*}{2} & The financial & & & & & & & & & & & & & 7 \\
\hline & $\begin{array}{l}\text { reports state all } \\
\text { the bank's } \\
\text { activities. }\end{array}$ & 1 & 1 & 4 & 3.8 & 11 & 10.5 & 43 & 41 & 46 & 43.8 & 4.23 & .858 & \\
\hline \multirow[t]{2}{*}{3} & the accounting & & & & & & & & & & & & & 8 \\
\hline & $\begin{array}{l}\text { information fits } \\
\text { the needs of } \\
\text { investors. }\end{array}$ & 1 & 1 & 1 & 1 & 14 & 13.3 & 49 & 46.7 & 40 & 38.1 & 4.20 & .777 & \\
\hline \multirow[t]{3}{*}{4} & The financial & & & & & & & & & & & & & 3 \\
\hline & $\begin{array}{l}\text { reports are } \\
\text { published for } \\
\text { more than a year }\end{array}$ & 1 & 1 & 1 & 1 & 11 & 10.5 & 41 & 39 & 51 & 48.6 & 4.33 & 0.780 & \\
\hline & $\begin{array}{l}\text { to make a } \\
\text { comparison in } \\
\text { performance. }\end{array}$ & & & & & & & & & & & & & \\
\hline \multirow[t]{2}{*}{5} & The information & & & & & & & & & & & & & 6 \\
\hline & $\begin{array}{l}\text { contained in the } \\
\text { financial reports } \\
\text { is accurate. }\end{array}$ & 0 & 0 & 1 & 1 & 13 & 12.4 & 42 & 40 & 49 & 46.7 & 4.33 & .716 & \\
\hline \multirow[t]{2}{*}{6} & $\begin{array}{l}\text { The bank's } \\
\text { customers get }\end{array}$ & & & & & & & & & & & & & 5 \\
\hline & $\begin{array}{l}\text { the distributions } \\
\text { of their profits } \\
\text { periodically. }\end{array}$ & 0 & 0 & 0 & 0 & 15 & 14.3 & 40 & 38.1 & 50 & 47.6 & 4.33 & .716 & \\
\hline \multirow[t]{2}{*}{7} & $\begin{array}{l}\text { shareholders are } \\
\text { satisfied with }\end{array}$ & & & & & & & & & & & & & 2 \\
\hline & $\begin{array}{l}\text { the general } \\
\text { performance of } \\
\text { the bank. }\end{array}$ & 0 & 0 & 0 & 0 & 15 & 14.3 & 37 & 35.2 & 53 & 50.5 & 4.36 & .722 & \\
\hline \multirow[t]{3}{*}{8} & $\begin{array}{l}\text { The bank cares, } \\
\text { analyzes and } \\
\text { takes advantage }\end{array}$ & & & & & & & & & & & & & 1 \\
\hline & $\begin{array}{l}\text { takes advantage } \\
\text { of } \\
\text { customers' the } \\
\text { complaints }\end{array}$ & 0 & 0 & 2 & 1.9 & 14 & 13.3 & 28 & 26.7 & 61 & 58.1 & 4.41 & .793 & \\
\hline & Full axis & & & & & & & & & & & 4.36 & 0.430 & $\begin{array}{l}\text { Strongly } \\
\text { Agree }\end{array}$ \\
\hline
\end{tabular}

Table 12 shows that the overall trend is "strongly agree" to all the phrases of the axis by an arithmetic mean of 4.36 and a standard deviation of 0.430

\section{Testing Hypotheses:}

Main Hypothesis: there is a statistically significant effect for the audit committee properties on the quality of the information of the banking financial reports? Emerging sub-hypotheses are as follows:

1. There is a statistically significant impact for determining the functions and duties of the audit committee on the quality of the information of the banking financial reports.

2. There is a statistically significant effect of the independence of the audit committee on the quality of the information of the banking financial reports.

3. There is a statistically significant impact of the availability of the banking and accounting experience for the members of the audit committee on the quality of the information of the banking financial reports.

4. There is a statistically significant effect of the efficiency of the audit committees of the banks on the quality of the information of the banking financial reports. 
We will prepare a MANOCOVA table for testing the hypotheses through the following equation:

$\mathrm{Y}=\mathrm{B} 0+\mathrm{B} 1 \mathrm{X} 1+\mathrm{B} 2 \mathrm{X} 2+\mathrm{B} 3 \mathrm{X} 3+\mathrm{B} 4 \mathrm{X} 4+\mathrm{e}$

$\mathrm{Y}$ : represents the dependent variable (the quality of the information of the banking financial reports)

$\mathrm{X} 1$ : the independent variable (the functions and duties of the audit committee)

$\mathrm{X} 2$ : the independent variable (the Committee's independence in the banks)

X3: independent variable (the availability of the banking and accounting experience of the members of the audit committee)

X4: the independent variable (the efficiency of the audit committees in banks)

B0: represents the division

(B1, B2, B3.B4): regression coefficients

Table 13. Estimation of multiple linear regression model to test all the variables

\begin{tabular}{lllll}
\hline Variables & coefficient & Standard error & Statistical T. & Potential value \\
\hline $\mathrm{C}$ & 2.980 & .352 & 8.473 & .055 \\
$\mathrm{X} 1$ & -.114 & .059 & -1.942 & .838 \\
$\mathrm{X} 2$ & .022 & .105 & .205 & .813 \\
$\mathrm{X} 3$ & -.023 & .099 & -.237 & .000 \\
$\mathrm{X} 4$ & .432 & .081 & 5.349 & .055 \\
R-squared & .293 & & & \\
Adjusted R-squared & .265 & & & \\
SE of regression & 0.368 & & & \\
Sum squared reside & $13: 56$ & & & \\
F-statistic & $10: 38$ & & & \\
Prob (F-statistic) & 0.000 & & & \\
\hline
\end{tabular}

Table 13 shows that all the variables are statistically insignificant with the exception of variable $\mathrm{x} 3$, which is the availability of the banking and accounting experience. As for the level of the model as a whole, we note that the possible value of $(\mathrm{P})$ was $(0.000)$, which is less than 0.05 ; this confirms that all the independent variables explain the quality of the accounting information of the banks at the community level and not on the study sample, which means that the study sample is not enough or not random. But if we look at the value of the determination coefficient (0.29), it means that the variables explain (29\%) of the difference in the banks' accounting information and (71\%) is explained by other factors outside the model frame.

This also leads us to having doubts in the existence of multiple correlations among variables. If there is a linear correlation between two independent variables, this will necessarily lead to making the statistically significant variables non-significant, which leads to increasing the standard error rate, which in turn leads to a lower possible value of $(\mathrm{T})$; this will make the possible value high making the statistically significant values non-significant; we will conduct a test for the multiple correlation among the independent variables through the independent variables matrix and detect the variables that caused the problem, delete it and then assess the model again.

Table 14. correlation matrix

\begin{tabular}{lllll}
\hline $\mathrm{X} 4$ & $\mathrm{X} 3$ & $\mathrm{X} 2$ & $\mathrm{X} 1$ & $\mathrm{X} 1$ \\
\hline .236 & .416 & .505 & 1.000 & $\mathrm{X} 2$ \\
.540 & .677 & 1.000 & .505 & $\mathrm{X} 3$ \\
.525 & 1.000 & .677 & .416 & $\mathrm{X} 4$ \\
1.000 & .525 & .540 & .236 & \\
\hline
\end{tabular}

From the matrix above, we noticed that the variables $(\mathrm{X} 1, \mathrm{X} 2)$ represent a high correlation ratio; we also note from the first regression model of table (13) the high possible value of the two variables $(0.838,0.818)$, respectively because there is a statistical base stating that the greater the possible value of the variable, the less the statistical significance; therefore, we will assess the model after deleting the variables separately.

Estimation of the multiple regression model for the regression line equation after de leting variable (X1):

$\mathrm{Y}=\mathrm{B} 0+\mathrm{B} 2 \mathrm{X} 2+\mathrm{B} 3 \mathrm{X} 3+\mathrm{B} 4 \mathrm{X} 4+\mathrm{e}$ 
Table 15. MANOCOVA Estimation after deleting variable (x1)

\begin{tabular}{lllll}
\hline Variables & Coefficient & Standard error & statistical T. & Potential value \\
\hline $\mathrm{C}$ & 2.863 & .351 & 8.151 & .000 \\
$\mathrm{X} 2$ & -.048 & .100 & -.483 & .630 \\
$\mathrm{X} 3$ & -.049 & .099 & -.496 & .621 \\
$\mathrm{X} 4$ & .445 & .082 & 5.457 & .000 \\
$\mathrm{R}$-squared & .267 & & & \\
Adjusted R-squared & .245 & & & \\
SE of regression & .373 & & & \\
Sum squared reside & $14: 07$ & & & \\
F-statistic & $12: 25$ & & & \\
Prob (F-statistic) & 0.000 & & & \\
\hline
\end{tabular}

Table 15 shows that after the deletion of variable (x1), the statistical significance of variable $\mathrm{x} 3$ was the availability of the banking and accounting experience which was meant that the quality of the information of the banking financial reports depends on the availability of the banking and accounting experience. As for the level of the model as a whole, we note that through the possible value of $(\mathrm{P})$ which is $(0.000)$ that is less than $(0.05)$; this confirms that all the independent variables (the functions and duties of the audit committee, the Committee's independence, the availability of the banking and accounting experience of the members of the audit committee, and the efficiency of the banks' audit committees) explain the quality of accounting information of the banks at the community level and not at the level of the study sample; this means that the study sample may be inadequate or not random. Howe ver, if we look at the value of the determination coefficient which is $(0.28)$, this means that the variables explain $(28 \%)$ of the difference in the accounting information of the banks and the rest $(72 \%)$ is explained by other factors outside of the model form.

Estimation of the multiple regression model for the regression line equation after deleting variable (X2):

$\mathrm{Y}=\mathrm{B} 0+\mathrm{B} 1 \mathrm{X} 1+\mathrm{B} 3 \mathrm{X} 3+\mathrm{B} 4 \mathrm{X} 4+\mathrm{e}$

Table 16. MANOCOVA estimation after deleting variable (X2)

\begin{tabular}{lllll}
\hline Variables & coefficient & Standard error & statistical T. & Potential value \\
\hline $\mathrm{C}$ & 2.995 & .343 & 8.733 & .000 \\
$\mathrm{X} 2$ & -.014 & .087 & -.161 & .873 \\
$\mathrm{X} 3$ & .437 & .077 & 5.710 & .000 \\
$\mathrm{X} 4$ & -.110 & .055 & -2.002 & .048 \\
R-squared & .273 & & & \\
Adjusted R-squared & .272 & & & \\
SE of regression & .366 & & & \\
Sum squared reside & $13: 57$ & & & \\
F-statistic & 13.96 & & & \\
Prob (F-statistic) & 0.000 & & & \\
\hline
\end{tabular}

Table 16 shows that after the deletion of variable (x2), the statistical significance of variables $\mathrm{x} 3$ and $\mathrm{x} 4$ which were the availability of the banking and accounting experience and the proficiency of the audit committees in the banks depending on the availability of the banking and accounting experience and the proficiency of the banks' committees. As for the level of the model as a whole, we note that through the possible value of $(\mathrm{P})$ which is $(0.000)$ that is less than (0.05); this confirms that all the independent variables (the functions and duties of the audit committee, the Committee's independence, the availability of the banking and accounting experience of the members of the audit committee, and the efficiency of the banks' audit committees) explain the quality of the accounting information of the banks at the community level and not at the level of the study sample; this means that the study sample may be inadequate or not random. However, if we look at the value of the determination coefficient which is (0.27), this means that the variables explain $(27 \%)$ of the difference in the accounting information of the banks and the rest (73\%) is explained by other factors outside of the model form.

Some of the criteria for selecting the appropriate model of assessment: the significance of the independent variables -the current possible value of $(\mathrm{P})$ must be signific antly less than $(0.05)$-the determination coefficient value must be larger than (60\%) -the coefficient value should be consistent with the economic theory or be consistent with the proper expectation. 
Table 17. Criteria of choosing model

\begin{tabular}{|c|c|c|c|c|}
\hline Sample & $\begin{array}{l}\text { Significance } \\
\text { variables }\end{array}$ & $P$ value & $\begin{array}{ll}\text { value of the } \\
\text { coefficient } \\
\text { determination }\end{array}$ & $\begin{array}{l}\text { Coefficients } \\
\text { Reference }\end{array}$ \\
\hline All variables & One variable & 0.00 & 0.29 & Compatible \\
\hline $\begin{array}{l}\text { After deleting variable } \\
(\mathrm{x} 1)\end{array}$ & One variable & 0.00 & 0.27 & Compatible \\
\hline $\begin{array}{l}\text { After deleting variable } \\
(\mathrm{X} 2)\end{array}$ & $\begin{array}{l}\text { Significance of two } \\
\text { variables }\end{array}$ & 0.00 & 0.27 & Compatible \\
\hline
\end{tabular}

From the table above, we find that the right model for estimation was the MANOCOVA after deleting variable (X2), Table (16).

\section{Results and Recommendations}

\subsection{Results}

Through the theoretical framework of the study and the field study, we have reached the following results: the study found that the availability of the audit committees properties affect in increasing the quality of the financial reports in the Saudi banks at the level of the properties as a whole as the possible value of $(\mathrm{P})$ was $(0.000)$ which is smaller than (0.05), which are (the functions and duties of the audit committee, the Committee's independence, the availability of the banking and accounting experience for the members of the audit committee and the efficiency of the audit committees in banks); the highest rates of the approval of the study sample on the axes of the study were as follows:

1. Issuing the audit committee reports within the annual reports of the bank so that the committee can perform and follow up its tasks to issue the committee report within the bank reports.

2. There are procedures, laws and regulations that control the job of the audit committee, which confirms the independence of audit committees and the fact that they have laws and procedures that organize their tasks.

3. The members of the audit committee focus on studying and understanding the internal control system which is a proof for the availability of the accounting and banking experience of the members of the audit committees in the Saudi banks.

4. The Audit Committee reports are submitted to the board of directors directly, which confirms the availability of the property of independence and the efficiency of the audit committee in the Saudi banks.

\subsection{Recommendations}

Through the results of the study, the researchers recommended the following:

1. The need the banks focus on the audit committees' properties to play their part as required.

2. More focus on the diversity of the experiences of the members of the audit team so that the committee can perform its functions more efficiently.

3. The need to develop a guide explaining the characteristics and functions of each member of the audit committee.

4. Working on supporting the independence of the audit committee in banks and activating their role in a greater method.

\section{References}

Abu Al-Soud, M. (2005). the role of internal audit in corporate governance, a research presented at the First Arab Conference for Internal Audit in the context of the Cairo corporate governance: the Arab Organization for Administrative Development, September, 24-26.

Accounting Standards Board of the Financial Accounting Commission of Banks and Financial and Islamic Institutions. (1994). Financial Accounting objectives and concepts, display standard, general disclosure and information on the commission (Bahrain: financial accounting commission of banks and financial Islamic institutions).

Adeniz, A., \& Lbock, J. (2005). auditing integrated introduction-translated by Mohammad Abd Al-Qader, (Riyadh: Al-Marikh house for publication).

Al-Ashmawi, M. A. A. (2006). the impact of audit committees on the information quality in the financial reports, MA Research in Accounting, unpublished, Faculty of Commerce, Ain Shams University. 
Al-Ashmawi, M. A. A. (2006). the internal auditing within the framework of corporate governance, public and private corporate governance seminar for economic and structural reform, Cairo: The Arab Organization for Administrative Development, 19-23 November.

Al-Dahrawi, K. A. (2004). analysis of financial statements for investment purposes (Alexandria: Al-Dar AlJamie'ia).

Al-fdag, F. (2002). Intermediate Accounting (Amman: Al-Warraq Foundation for Publishing).

Al-Hassan, O., Al-Sir, S., \& Ismail, M. A. (2015), Analytical Study between the audit committees and reducing the expectations gap in reviewing the Sudanese business environment, research published in the Applied Egyptian Journal in Sharqia, 30(VIII).

Ali, S. H. M. (2013). the role of audit committees in the effectiveness of the internal control of the Sudanese banks-field study, research published in the Journal of Administrative Sciences of Scientific Research, Faculty of Administrative Sciences, International University of Africa, the first issue.

Al-Kebaji, M. W. (2015). the effectiveness of the role of audit committees in fighting money Laundering-Empirical Study on the banks operating in Palestine, research published in the Jordanian Journal of Business Administration (Jordan), Volume 11, Issue 1

Al-Matari, Y. A., Abdo, A. H., \& Hassan, A. (2016). The Influence of Audit Committee Effectiveness on Banks' Performance in Yemen. International Journal of Economics and Financial Issues, 6(4).

Al-Saqqa, A. M. (1995). a proposed theoretical framework to measure and de velop the effectiveness of the audit committees in the Saudi joint stock companies . Trade and Finance Journal, Tanta University, 2.

Al-Sartawi, A. A. (2013) the impact of the audit committees in the Jordanian public shareholding companies on reducing the profits management-An Empirical Study. Research Journal of Al-Najah University"Humanities", Nablus, Palestine, 27(4).

Al-Wabil, Wabil Bin Ali, (1996). Determinants and Effectiveness of audit committees in the shareholding companies in the Kingdom of Saudi Arabia (Case Study), published research, Journal of Commerce for Scientific Research, Alexandria University, First Issue. FASB, Minutes of the 25, (2006),Board Meeting Conceptual Frame Work Qualitative Characteristics.

Attia, H. A. (1999). Introduction to Accounting Information Systems (Alexandria: Al-Dar AlJamie'ia)

Hamdan, A. M. et.al. (2012). the role of the audit committees in the continuity of the profits as a sign of quality, research published in the Jordanian Journal of Business Administration, Deanship of Scientific Research, University of Jordan, 8(III).

Hammad, T. A. (2005). Financial Reports (Alexandria, Al-Dar AlJamie'ia, 2005).

Hammad, T. A. A. (2006). the accountant guide towards the application of the modern international financial reporting standards, (Alexandria: Al-Dar AlJami'ia).

Hanan, R. H. (2003). the contemporary Accounting model (Amman: Wail house for Publishing and Distribution).

Jarbou', Y. M. (2001). Accounting Theory (Amman: Al-Warraq Foundation for Publishing and Distribution)

Khallat, S. M., \& Masli, A. A. M. (2014). the role of audit committees in supporting the efficiency and effectiveness of the internal audit function in the Libyan industrial companies, research published in the scientific journal, Misrta University, 1(XVI).

Labib, A. A. (2011). improving the effectiveness of audit committees to increase the credibility of financial statements, research published in the Journal of accounting thought, Faculty of Commerce, Ain Shams University, 15, First Issue.

Mal, K. O., Babangida, I. T., \& Monica, S. (2015). Audit Committee Independence, Meeting Frequency, Attendance and Financial Reporting Quality of Listed Deposit Money Banks in Nigeria. Research Journal of Finance and Accounting, l.6(18).

Memullen, D. N. (1996). Audit committee performance: an investigation of the consequences associated with audit committee. Journal of Practice and Theory, 15(1).

Nasr, A. A., \& Shehata, A. (2006). supervision and modern audit in the IT environment and the globalization of financial markets, (Alexandria: Al-Dar AlJamie'ia). 
Noland et.al, Thomas, G., Nichols, D. L., \& Flesher, D. L. (2004). Audit Committee Effectiveness in the Banking Industry. Management Accounting Quarterly, 5(3).

Qutaishat, A. K. A. (2010). the availability of the necessary conditions for improving the effectiveness of the audit committees formed in the Jordanian public shareholding companies, MA research in Accounting, Middle East University, College of Business, Jordan.

Rachman, G. G. (2014). The Effect of Board of Commissioners, Audit Committee, and Internal Auditor on Financial Reporting Quality of Banks Listed on the Indonesia Stock Exchange. International Journal of Economics, Commerce and Management, II(10),

Radi, M. S. (2004). Intermediate Accounting (Alexandria: Al-Dar AlJamie'ia).

Radi, M. S. (2010). Advanced Audit Encyclopedia, (Alexandria: university education house).

Schadéwitz, H., \& Turley, S. (2008). The Effect of Audit Quality on the Relationship between Audit Committee Effectiveness and Financial Reporting Quality, Universitas Wasaensis, ACTA Wasaensia No 197, Business Administration 80, Accounting and Finance .

Sori, Z. M., Shamsher, M. R., \& Yusuf, K. (2009). Audit Committee and Auditor Independence: The Bankers' Perception. Journal of Economics and Management, 3(2).

Yuanto, K., Leong, K., \& Suwardy, T. (2016). Audit Committees and Financial Reporting Quality in Singapore. Journal of Business Ethics, 139(1).

\section{Copyrights}

Copyright for this article is retained by the author(s), with first publication rights granted to the journal.

This is an open-access article distributed under the terms and conditions of the Creative Commons Attribution license (http://creativecommons.org/licenses/by/4.0/). 